Bull. Chem. Soc. Ethiop. 2006, 20(1), 9-15.

ISSN 1011-3924

Printed in Ethiopia

(c) 2006 Chemical Society of Ethiopia

\title{
ANALYSIS OF VEHICULAR FALLOUTS FROM TRAFFIC IN THE KUMASI METROPOLIS, GHANA
}

\author{
D.K. Essumang ${ }^{*}$, D.K. Dodoo, S. Obiri, and B.A.K. Oduro
}

Department of Chemistry, University of Cape Coast, Cape Coast, Ghana

(Received April 8, 2005; revised August 8, 2005)

\begin{abstract}
Concentrations of platinum, lead, cadmium, copper, and zinc in dust from areas of high, medium, low and very low vehicular movements in Kumasi Metropolis in the Ashanti Region of the Republic of Ghana was measured. High concentrations of platinum, lead, copper, and zinc were found to be associated with soils from areas of high traffic densities suggesting that vehicles (that ply these areas) also contribute heavy metals to the environment. The results of the study shows that the road and users, like residents living in buildings within these areas, those engaged in commercial activities like hawking, and the general public are at risk of exposure to the toxic effects of $\mathrm{Pt}, \mathrm{Pb}, \mathrm{Cd}, \mathrm{Cu}$, and $\mathrm{Zn}$ as they inhale those metals released from the exhaust of vehicles into the environment. According to these results, there is the potential for exposure to high levels of $\mathrm{Pt}, \mathrm{Cd}, \mathrm{Pb}, \mathrm{Cu}$, and $\mathrm{Zn}$ for road users and those living in urban environments or along the highways.
\end{abstract}

KEY WORDS: Catalytic converter, Vehicular fallouts, Toxic metals, High, Medium, Low and Very low traffic conditions, Kumasi Metropolis (Ghana).

\section{INTRODUCTION}

High urbanization and industrial growth have made Kumasi one of the most densely populated cities in Ghana. This has resulted in an increase in the number of vehicles that ply the metropolis each day. Uncontrolled emissions from industries, release of toxic wastes from industrial and domestic activities coupled with emissions of toxic chemicals from the exhaust of vehicles have increased the levels of pollutant in the metropolis. Emissions from vehicles contain a variety of toxic chemicals such as platinum and palladium from catalytic converters and $\mathrm{Pb}$ from vehicles that run on leaded petrol. Ni is emitted from diesel vehicles, $\mathrm{Zn}$ and $\mathrm{Cd}$ from vehicular tyres and $\mathrm{Cu}$ from brakes linings and electrical wires. These toxic chemicals accumulate in the nearby soil, in the surfaces of leaves of plants grown along the highways, in surface waters, foodstuffs sold along the highways and in the hairs of individuals who are actively engaged in commercial activities in these high vehicular traffic environments.

Studies conducted in developed countries such as Japan, United States of America (USA), etc, have revealed that the concentration of platinum in soils along highways ranges between 50 $\mathrm{ppb}$ to $0.5 \mathrm{ppm}$, whereas the crystal abundance of $\mathrm{Pt}$ in soil is about $1.5 \mathrm{ppb}$ [4, 5]. $\mathrm{Pt}, \mathrm{Cd}, \mathrm{Cu}$, $\mathrm{Pb}$, and $\mathrm{Zn}$ in soils may form chemical complexes and get mobilized into ground water and finally into the food chain. The toxic effects of $\mathrm{Pt}, \mathrm{Cd}, \mathrm{Cu}, \mathrm{Pb}$, and $\mathrm{Zn}$ and its compounds have been found to be hazardous to the ecosystem and human beings in general even at very low concentrations [1-6].

The possible hazards effects arising from pollution of the environment by these heavy metals from emissions of vehicles to children, adults and the ecosystem in developing countries have not been studied extensively such as Ghana. It is against this background that this study was conducted to determine the levels of $\mathrm{Pt}, \mathrm{Cu}, \mathrm{Cd}, \mathrm{Pb}$, and $\mathrm{Zn}$ in wayside dusts

*Corresponding author. E-mail: kofiessumang@yahoo.com 
along high and low vehicular traffic areas in the Kumasi Metropolis of the Republic of Ghana. The main thrust of this paper is to: (i) determine whether catalytic converters in motor vehicles have any effect on the environment in the Kumasi environment and (ii) measure the levels of heavy metals in soil with respect to vehicular or automobile emissions.

\section{EXPERIMENTAL}

\section{Sampling techniques}

Random sampling techniques were adopted to select the following traffic points in the Kumasi Metropolis (i.e. high, medium, low and very low traffic densities). Each sampling point was zoned into four different sampling points and soil samples were obtained from each zone between November 2002 and April 2003 as shown in Table 1. Sample from each zone was analysed separately and the mean computed.

Table 1. Sampling sites and number of samples obtained.

\begin{tabular}{|l|l|l|l|l|l|}
\hline \multirow{2}{*}{ Sampling point } & \multicolumn{3}{|c|}{ Number of samples } & \multirow{2}{*}{ Total } \\
\cline { 2 - 6 } & Zone 1 & Zone 2 & Zone 3 & Zone 4 & \\
\hline High vehicular traffic & 8 & 8 & 8 & 8 & 32 \\
\hline Medium vehicular traffic & 8 & 8 & 8 & 8 & 32 \\
\hline Low vehicular traffic & 8 & 8 & 8 & 8 & 32 \\
\hline Very low vehicular traffic & 8 & 8 & 8 & 8 & 32 \\
\hline Total & 32 & 32 & 32 & 32 & 128 \\
\hline
\end{tabular}

\section{Sample collection and preparation}

Surface soil samples exposed to different traffic conditions were collected from different parts of Kumasi over a period of two months. Approximately $100 \mathrm{~g}$ of soil sample were collected into plastic containers from the street dust under different traffic conditions and conveyed into the laboratory for analysis. In the laboratory, the soil samples were air dried for 48 hours and sieved using $200 \mu \mathrm{m}$ mesh.

\section{Digestion of soil samples and analysis of soil samples for $\mathrm{Pt}, \mathrm{Pb}, \mathrm{Cd}, \mathrm{Cu}$, and $\mathrm{Zn}$}

$2.0 \mathrm{~g}$ of soil samples were weighed into $250 \mathrm{~mL}$ beakers. $10 \mathrm{~mL}$ of $36 \%$ conc. $\mathrm{HCl}$ (AR $\mathrm{HCl}$, $\mathrm{BDH} \mathrm{UK}$, trace impurities $\mathrm{Pb}=0.000005 \%$, $\mathrm{As}=0.000002 \%, \mathrm{Cu}=0.0001 \%$, and $\mathrm{Fe}=$ $0.000005 \%$ ) was first added and after $30 \mathrm{~min} 10 \mathrm{~mL}$ of $63 \% \mathrm{HNO}_{3}$ (analytical grade, BDH UK, trace impurities $\mathrm{Ni}=0.000005 \%, \mathrm{Co}=0.000005 \%, \mathrm{Cd}=0.000005 \%, \mathrm{Fe}=0.000005 \%, \mathrm{~Pb}=$ $0.000005 \%$, and $\mathrm{Cu}=<0.0005 \%$ ) was also added. The temperature for the dissolution process was at $30{ }^{\circ} \mathrm{C}$. The mixture was allowed to settle for over two hours after which $10 \mathrm{~mL}$ of $\mathrm{HClO}_{4}$ was added. The mixture was heated until the colour of the solution became clear from the initial yellowish appearance. The beakers were then removed from the hot plate, allowed to cool and the solution filtered using Whatman No. 41 filter paper into a $50 \mathrm{~mL}$ volumetric flask. The filtrate was then made up to the $50 \mathrm{~mL}$ mark. The digested samples were used for analysis of $\mathrm{Pt}$, $\mathrm{Zn}, \mathrm{Pb}, \mathrm{Cd}$, and $\mathrm{Cu}$ using UNICAM 929 Flame Atomic Absorption Spectrophotometer (AAS). Blank and standard samples were used to zero and calibrate the instrument after which the samples were aspirated into the AAS. 


\section{RESULTS AND DISCUSSION}

\section{Recovery and reproducibility studies}

To check the sensitivity and efficiency of the method used in the chemical analysis, recovery and reproducibility studies were conducted.

In the recovery studies, known certified concentrations of $\mathrm{Pt}, \mathrm{Zn}, \mathrm{Pb}, \mathrm{Cu}$, and $\mathrm{Cd}$ were determined using the flame AAS. The results are given Table 2.

Table 2. Results of $\mathrm{Pt}, \mathrm{Zn}, \mathrm{Cu}, \mathrm{Pb}$, and $\mathrm{Cd}$ recovery studies.

\begin{tabular}{|c|c|c|c|c|c|}
\hline \multirow[t]{2}{*}{ Concentration $\mu \mathrm{g} / \mathrm{L}$} & \multicolumn{3}{|c|}{ Amount recovered $(\mu \mathrm{g} / \mathrm{L})$} & \multirow[t]{2}{*}{ Percentage recovered } & \multirow[t]{2}{*}{ Standard deviation } \\
\hline & 1 & 2 & Mean & & \\
\hline \multicolumn{6}{|l|}{ Platinum } \\
\hline 0.20 & 0.19 & 0.19 & 0.19 & 95 & 0.00 \\
\hline 0.40 & 0.41 & 0.38 & 0.40 & 100.0 & 0.02 \\
\hline 0.80 & 0.81 & 0.77 & 0.79 & 98.8 & 0.02 \\
\hline 1.00 & 0.98 & 0.98 & 0.98 & 100.0 & 0.00 \\
\hline \multicolumn{6}{|l|}{ Zinc } \\
\hline 0.20 & 0.19 & 0.19 & 0.19 & 95 & 0.00 \\
\hline 0.40 & 0.41 & 0.38 & 0.40 & 100.0 & 0.02 \\
\hline 0.80 & 0.81 & 0.77 & 0.79 & 98.8 & 0.02 \\
\hline 1.00 & 0.98 & 0.98 & 0.98 & 100.0 & 0.00 \\
\hline \multicolumn{6}{|l|}{ Copper } \\
\hline 0.20 & 0.19 & 0.22 & 0.21 & 105 & 0.02 \\
\hline 0.40 & 0.38 & 0.40 & 0.39 & 97.5 & 0.01 \\
\hline 0.80 & 0.78 & 0.78 & 0.78 & 97.5 & 0.00 \\
\hline 1.00 & 1.02 & 0.98 & 1.00 & 100 & 0.03 \\
\hline \multicolumn{6}{|l|}{ Lead } \\
\hline 0.20 & 0.19 & 0.22 & 0.21 & 105 & 0.02 \\
\hline 0.40 & 0.38 & 0.40 & 0.39 & 97.5 & 0.01 \\
\hline 0.80 & 0.78 & 0.78 & 0.78 & 97.5 & 0.00 \\
\hline 1.00 & 1.02 & 0.98 & 1.00 & 100 & 0.03 \\
\hline \multicolumn{6}{|l|}{ Cadmium } \\
\hline 0.20 & 0.19 & 0.22 & 0.21 & 105 & 0.02 \\
\hline 0.40 & 0.38 & 0.40 & 0.39 & 97.5 & 0.01 \\
\hline 0.80 & 0.78 & 0.78 & 0.78 & 97.5 & 0.00 \\
\hline 1.00 & 1.02 & 0.98 & 1.00 & 100 & 0.03 \\
\hline
\end{tabular}

The result in Table 2 shows that the percentage recoveries of the metals from double distilled water are between 95 and $105 \%$ with a standard deviation between 0.00 and 0.03 . This suggests that the method used is very efficient.

The reproducibility studies were carried out by analyzing double distilled water containing 2 $\mathrm{mg} / \mathrm{L}$ of $\mathrm{Pt}$ and $1 \mathrm{mg} / \mathrm{L}$ of $\mathrm{Zn}, \mathrm{Cu}, \mathrm{Pb}$, and $\mathrm{Cd}$, separately and respectively, using flame AAS. The results are given in Table 3 . From Table 3 it is clear that the methods used in analysing Pt, $\mathrm{Zn}, \mathrm{Cu}, \mathrm{Pb}$ and $\mathrm{Cd}$ in the samples is reproducible.

Similarly, to determine the efficiency of the digestion process, $0.5 \mu \mathrm{g} / \mathrm{L} \mathrm{Pt}, \mathrm{Zn}, \mathrm{Cu}, \mathrm{Pb}$, and $\mathrm{Cd}$ solution were used to spike the samples. The concentration in the spiked samples of Pt, $\mathrm{Zn}$, $\mathrm{Cu}, \mathrm{Pb}$, and $\mathrm{Cd}$ were determined as described above. Table 4 shows quadruplicate results of such experiments. From the results shown in Table 4, it is clear that the digestion processes for the recovery of $\mathrm{Zn}, \mathrm{Cu}, \mathrm{Pb}$ and $\mathrm{Cd}$ in the sample are very efficient. 
Table 3. Reproducibility of recovery of $\mathrm{Pt}, \mathrm{Zn}, \mathrm{Cu}, \mathrm{Pb}$ and $\mathrm{Cd}$ from aqueous solution.

\begin{tabular}{|c|c|c|c|c|c|c|c|c|c|c|}
\hline Platinum & 1 & 2 & 3 & 4 & 5 & 6 & 7 & 8 & 9 & 10 \\
\hline $\begin{array}{l}\text { Amount } \\
\text { added } 2 \mu \mathrm{g} / \mathrm{L}\end{array}$ & 1.93 & 1.98 & 1.96 & 2.01 & 1.99 & 1.96 & 1.99 & 2.02 & 2.03 & 1.99 \\
\hline Zinc & 1 & 2 & 3 & 4 & 5 & 6 & 7 & 8 & 9 & 10 \\
\hline $\begin{array}{l}\text { Amount } \\
\text { added } 1 \mu \mathrm{g} / \mathrm{L}\end{array}$ & 0.969 & 0.974 & 1.014 & 1.010 & 1.002 & 0.988 & 0.991 & 0.994 & 1.021 & 0.995 \\
\hline \multicolumn{11}{|l|}{ Copper } \\
\hline $\begin{array}{l}\text { Amount } \\
\text { added } 1 \mu \mathrm{g} / \mathrm{L}\end{array}$ & 0.974 & 0.969 & 1.021 & 0.988 & 1.010 & 1.002 & 0.991 & 0.994 & 0.995 & 1.014 \\
\hline \multicolumn{11}{|l|}{ Lead } \\
\hline $\begin{array}{l}\text { Amount } \\
\text { added } 1 \mu \mathrm{g} / \mathrm{L}\end{array}$ & 1.010 & 0.969 & 1.014 & 1.002 & 0.974 & 0.988 & 0.991 & 1.021 & 0.995 & 0.994 \\
\hline \multicolumn{11}{|l|}{ Cadmium } \\
\hline $\begin{array}{l}\text { Amount } \\
\text { added } 1 \mu \mathrm{g} / \mathrm{L}\end{array}$ & 1.002 & 0.969 & 1.014 & 0.974 & 1.010 & 0.988 & 1.021 & 0.994 & 0.995 & 0.9911 \\
\hline
\end{tabular}

Percentage recovered $=>99.3 ;$ standard deviation $=0.017-0.029 ;$ standard error $=0.005-0.009$; coefficient of variation $=1.6-1.7 \%$.

Table 4. Percentages of $\mathrm{Pt}, \mathrm{Zn}, \mathrm{Cu}, \mathrm{Pb}$ and $\mathrm{Cd}$ recovered from $(0.5 \mu \mathrm{g} / \mathrm{L})$ spiked solutions.

\begin{tabular}{|c|c|c|c|c|c|c|}
\hline Replicate & 1 & 2 & 3 & 4 & Mean & SD \\
\hline \multicolumn{7}{|l|}{ Platinum } \\
\hline Amount recovered, $\mu \mathrm{g} / \mathrm{L}$ & 0.48 & 0.46 & 0.51 & 0.48 & 0.48 & 0.02 \\
\hline Percentage recovered & 96.0 & 92.0 & 102.0 & 96.0 & 96.5 & 4.12 \\
\hline \multicolumn{7}{|l|}{ Zinc } \\
\hline Amount recovered, $\mu \mathrm{g} / \mathrm{L}$ & 0.46 & 0.48 & 0.48 & 0.52 & 0.49 & 0.03 \\
\hline Percentage recovered & 92.0 & 96.0 & 96.0 & 104.0 & 97.0 & 5.03 \\
\hline \multicolumn{7}{|l|}{ Copper } \\
\hline Amount recovered, $\mu \mathrm{g} / \mathrm{L}$ & 0.47 & 0.47 & 0.48 & 0.51 & 0.48 & 0.02 \\
\hline Percentage recovered & 94.0 & 94.0 & 96.0 & 102.0 & 96.5 & 3.78 \\
\hline \multicolumn{7}{|l|}{ Lead } \\
\hline Amount recovered, $\mu \mathrm{g} / \mathrm{L}$ & 0.49 & 0.52 & 0.46 & 0.49 & 0.49 & 0.02 \\
\hline Percentage recovered & 98.0 & 104.0 & 92.0 & 98.0 & 96.5 & 4.89 \\
\hline \multicolumn{7}{|l|}{ Cadmium } \\
\hline Amount recovered, $\mu \mathrm{g} / \mathrm{L}$ & 0.50 & 0.48 & 0.46 & 0.49 & 0.48 & 0.03 \\
\hline Percentage recovered & 100.0 & 96.0 & 92.0 & 98.0 & 96.5 & 3.42 \\
\hline
\end{tabular}

The concentrations of heavy metals such as $\mathrm{Pb}, \mathrm{Cd}, \mathrm{Cu}, \mathrm{Zn}$, and $\mathrm{Pt}$ in different soil categories in Kumasi are shown in Table 5. These soil samples are grouped under different traffic conditions such as high, medium, low and very low traffic densities, respectively.

From Table 5, most of the heavy metals analyzed showed an increase in concentration at places where the traffic density was high. For $\mathrm{Pt}, \mathrm{Pb}, \mathrm{Zn}$, and $\mathrm{Cu}$ increased as the traffic conditions increased from very low to high. The concentration range was between 12.95 to $32.51 \mu \mathrm{g} / \mathrm{g}$ for lead, 29.98 to $60.26 \mu \mathrm{g} / \mathrm{g}$ for copper, 102.65 to $320.65 \mu \mathrm{g} / \mathrm{g}$ for zinc, and 0.001 to $0.004 \mu \mathrm{g} / \mathrm{g}$ for platinum, respectively.

On the contrary, these increases were not observed for Cd (Table 5). The concentration of $\mathrm{Cd}$ in surface soil did not increase as the traffic density increased from very low to high. This means that the concentration of $\mathrm{Cd}$ did not show any significant changes under different traffic condition. As $\mathrm{Cd}$ is only present in the tyres of the vehicles and can only be released into the street soils in the event of burning of tyres of vehicles, which rarely occur in Kumasi metropolis.

Bull. Chem. Soc. Ethiop. 2006, 20(1) 
It can be observed that the concentration of $\mathrm{Pb}$ in the street of Kumasi increases as the vehicular traffic increases. Generally, high concentrations of $\mathrm{Pb}$ in street soil dust in high vehicular traffic conditions might also be due to accumulation from the previous use of leaded fuels in vehicles that ply the metropolis before the ban. It is possible that diethyl lead is still being added to the petrol to prevent knocking despite its ban worldwide. Although natural processes and other human activities such as the use of $\mathrm{Pb}$ base paints to paint artefacts or buildings can contribute significantly to high $\mathrm{Pb}$ pollution in soil in the metropolis, emission from automobiles can be said to be one of the major source of lead pollution in the metropolis as the concentration of lead obtained in the street soil under very low traffic condition was low and even lower than the background values as compared. The concentration of lead obtained from the analysis at the vehicular traffic point was low. This means that in areas, which are inaccessible to vehicular traffic, the concentration of $\mathrm{Pb}$ that will be obtained may be much lower than the lowest concentration of lead obtained in this work.

Table 5. Mean concentrations of heavy metals in surface soil/street dusts under different traffic conditions in Kumasi.

\begin{tabular}{|l|l|l|l|l|l|l|l|l|l|l|l|}
\hline \multirow{2}{*}{ Sample category } & $\mathrm{Pb}$ & $\mathrm{Cd}$ & $\mathrm{Cd}$ & $\mathrm{Cu}$ & \multicolumn{2}{l|}{$\mathrm{Zn}$} \\
\cline { 2 - 13 } & $\mu \mathrm{g} / \mathrm{g}$ & $\mathrm{SD}$ & $\mu \mathrm{g} / \mathrm{g}$ & $\mathrm{SD}$ & $\mu \mathrm{g} / \mathrm{g}$ & $\mathrm{SD}$ & $\mu \mathrm{g} / \mathrm{g}$ & $\mathrm{SD}$ & $\mu \mathrm{g} / \mathrm{g}$ & $\mathrm{SD}$ \\
\hline $\begin{array}{l}\text { High vehicular } \\
\text { traffic }\end{array}$ & 32.51 & 0.1 & 3.03 & 0.1 & 60.26 & 0.1 & 320.65 & 0.1 & 0.004 & 0.1 \\
\hline $\begin{array}{l}\text { Medium } \\
\text { vehicular traffic }\end{array}$ & 25.25 & 0.1 & 3.20 & 0.1 & 54.35 & 0.2 & 300.15 & 0.1 & 0.002 & 0.1 \\
\hline $\begin{array}{l}\text { Low } \\
\text { vehicular traffic }\end{array}$ & 15.35 & 0.1 & 2.80 & 0.1 & 45.01 & 0.1 & 200.50 & 0.1 & 0.001 & 0.1 \\
\hline $\begin{array}{l}\text { Very low } \\
\text { vehicular traffic }\end{array}$ & 12.95 & 0.1 & 3.00 & 0.0 & 29.98 & 0.1 & 102.65 & 0.1 & 0.001 & 0.0 \\
\hline
\end{tabular}

Although, the highest concentration of Pt obtained was very small, $(0.004 \mu \mathrm{g} / \mathrm{g})$ as compared to the other metals, Pt metal and its compounds are very dangerous even at very low concentrations and as such exposure to them may be harmful either to plants or animals including human beings and can cause several diseases. Pt as a metal is not very dangerous, but Pt salts can cause several health effects, such as: DNA alterations, cancer allergic reactions of the skin and the mucous membrane, damage to organs such as intestines, kidneys and bone marrow, and hearing damage [6]. Micro-organisms may be able to convert platinic substances to more dangerous substances in soils, which are later used by plants. Pt is emitted into air through the exhaust of cars that use leaded gasoline. Consequently, Pt levels in air may be higher in certain locations, for instance in garages, in tunnels and on terrains of trucking companies. The very low concentration of $\mathrm{Pt}$ can be attributed to the fact that, although $\mathrm{Pt}$ is used as a catalyst in catalytic converters to convert carbon monoxide $(\mathrm{CO})$ to carbon dioxide $\left(\mathrm{CO}_{2}\right)$, it is not the solid form of the metal which is used but rather a finely divided form of the metal $\mathrm{Pt}$ in the form of $\mathrm{Pt}$ sponge or Pt black that is used [6]. Hence, a small amount of Pt is used to coat the converters; hence the very low concentration of $\mathrm{Pt}$ in the street environment of Kumasi metropolis. The effects of Pt on animals, plants and the environment in general have not been studied extensively.

In the case of $\mathrm{Cu}$ and $\mathrm{Zn}$ under the same traffic conditions were obtained for low and very low traffic condition, the concentrations were found to be higher. This high increase in concentration for $\mathrm{Cu}$ and $\mathrm{Zn}$ may be due to other anthropogenic processes such as the use of galvanized steel tanks and rusting of $\mathrm{Cu}$ pipes. Although $\mathrm{Zn}$ is one of the most essential trace elements in human body, elevated levels of $\mathrm{Zn}$ in the environment can cause adverse health 
effects. That is, high $\mathrm{Zn}$ intakes greater than about twice RDA levels inhibit $\mathrm{Cu}$ absorption. $\mathrm{Zn}$ does this by stimulating synthesis of the mineral binding protein metallothionein. Studies have shown that $\mathrm{Zn}$ supplements at approximately 3 to 5 times than the RDA can reduce high density lipoprotein (HDL) by about $15 \%$ interfering with $\mathrm{Cu}$ metabolism. $\mathrm{Zn}$ intake over $100 \mathrm{mg} /$ day also results in diarrhea, abdominal cramps, nausea, vomiting and depressed immune system function especially if intake exceeds $2 \mathrm{mg} /$ day [7].

It was observed in Table 5 that the concentration of $\mathrm{Cd}$ in the streets of Kumasi did not change very much under different traffic conditions. This may be due to the fact that, the concentration of $\mathrm{Cd}$ in street soil dust is mainly from other anthropogenic sources and not necessary from fallouts of vehicular movement.

\section{CONCLUSION}

The results obtained shows that heavy metals content of surface street soils in Kumasi Metropolis is generally higher. These metals have adverse effect on the environment especially in the urban environment where there is a lot of vehicular traffic and as a result people living in the high vehicular area are at higher risk of being exposed to these metals. These metals when emitted into the atmosphere, larger particles will drop and pollute the soil or surface waters, the smaller particles are breathed in by human beings or travel long distances through the air and it can also remain in the atmosphere for a long period of time. They can settle on foodstuffs making them contaminated. High levels of heavy metals in soils may be absorbed by plants which are then transported and stored in their roots, leaves and fruits. Intake of such substances contaminated with these metals by animals or human beings for a long time can cause an increase in concentration of these metals in their body. Also contaminated roadside or street soil can constitute a health hazard if these metals are washed into nearby street or river where they bioaccumulation in fishes.

The effect of Pt on animals and the environment may be, has not yet been studied extensively in Ghana and elsewhere in the world. Pt will accumulate in the roots of plants after uptake from the soil or eating of platinum containing foods will also accumulate in the human body, its effect on the human is not yet known. However, it is believed that many microorganism convert platinum in soils to very harmful compounds that cause several health problems such as cancer allergic reactions, DNA alterations and mucous membrane destruction.

$\mathrm{Pb}$ is a particularly dangerous chemical, as it accumulates in individual organisms. Different health problems such as affecting intelligent quotient of children have found with children exposed to high concentration of lead in the environment. $\mathrm{Zn}, \mathrm{Cu}$, and $\mathrm{Cd}$ are all very toxic to human beings it is very important that their concentration in the environment is reduced to the barest minimum.

Hence, from the results of the study, it is clear that inhabitants of Kumasi and its surrounding areas or regional capitals in Ghana with very large traffic inflows are at risk of exposure to $\mathrm{Pt}, \mathrm{Cd}, \mathrm{Cu}, \mathrm{Zn}$, and $\mathrm{Pb}$. Pragmatic efforts should be taken to prevent individuals from been exposed to high concentrations of these metals in the environment.

\section{ACKNOWLEDGEMENT}

We wish to thank all the drivers in Kumasi for their patience and support during the sampling process. Finally, we wish to thank the Government of Ghana for the financial support through research and development fund. 


\section{REFERENCES}

1. Nriagu, J.O. Environment 1990, 32, 7.

2. Nriagu, J.O. Science 1996, 272, 223.

3. Fyfe, W.S. Science 1981, 213, 105.

4. Nriagu, J.O.; Pacyna, J.M. Nature 1988, 333, 134.

5. Siva, S.N.; Masuda, A.; Hirata, T. Symposium on Mass Spectrometry, $8^{\text {th }}$ ISMAS, Hyderabad, India, Proceedings, 1990; pp 535-537.

6. "Platinum", Microsoft@ Encarta ${ }^{\circledR}$ Online Encyclopedia 2005. http://encarta.msn.com ( 1997-2005 Microsoft Corporation.

7. US Environmental Protection Agency (USEPA, 2001a): Integrated Risk Information System (IRIS), Toxicity Database File. www.epa.gov/ngispm3/iris. 